УДК 392.51(=161.2)

DOI: 10.31866/2616-7646.3.2.2020.220536

\title{
ІГРОВИЙ РЕПЕРТУАР ТРАДИЦІЙНОГО ВЕСІЛЛЯ УКРАЇНЦІВ
}

\author{
Курочкін Олександр Володимирович, \\ доктор історичних наук, професор, \\ Київський національний університет культури і мистецтв, \\ Київ, Україна \\ https://orcid.org/0000-0002-3365-7266, \\ olexkurodgmail.com
}

Мета статті - визначити й проаналізувати основні типологічні блоки ігрового репертуару традиційного українського весілля в його завершальній - перезвянсько-карнавальній частині, де провідна роль належала представникам дорослої статево-вікової групи населення. Методологія. Дослідження проведене на основі міждисциплінарного підходу, шляхом системного аналізу літературних, документальних, етнографічних і фольклорних матеріалів. Наукова новизна. Проведене дослідження заповнює істотну прогалину у вивченні розважально-ігрової культури українців. Висновки. Переважно аграрний характер традиційної культури українців пояснює той факт, що головний масив репертуару перезвянської (другої) частини народного весілля складають ігрові практики, котрі імітують виробничу діяльність хлібороба. У контексті архаїчної свідомості трудові процеси тісно асоціювались із продуктивно-еротичною магією, покликаною забезпечити щастя й добробут новоствореної сім'ї. Ігри з яскраво вираженою еротичною символікою й атрибутикою, супроводжувані сороміцьким фольклором та експресивною лексикою, належать до найдавнішого пласту аграрної обрядовості. У традиційній перезві українців цю групу представляють ігри «Товкти ступу», «Забивання кілка» («Чопа»), «Показувати межу» й ін. До категорії імітаційних належать ігри: «Молотити жито» або «Сіяти жито», «Косар», «Коваль», «Мельник», «Токар», «Молотарка», «Комбайн» та ін. Спостережений нами у весільній звичаєвості прийом ігрового роздягання (оголення) $є$ антитезою карнавального рядження й маскування. Обидві ці ігрові практики є традиційними способами перенесення людей в атмосферу свята, де все «догори дригом», не так, як у буденному житті. Історична еволюція весільних обрядів ішла різними шляхами: найбільш варварські й архаїчні відмирали, а інші поступово перетворилися на народний самодіяльний театр, характерними ознаками якого є гумор, життєвй оптимізм, драматична імпровізація.

Ключові слова: весілля; обряд; гра; традиційні розваги; еротичний фольклор; народний гумор; святкове дозвілля. 


\section{ИГРОВОЙ РЕПЕРТУАР ТРАДИЦИОННОЙ СВАДЬБЫ УКРАИНЦЕВ}

\author{
Курочкин Александр Владимирович, \\ доктор исторических наук, профессор, \\ Киевский национальный университет \\ культуры и искусств, \\ Киев, Украина, \\ https://orcid.org/0000-0002-3365-7266, \\ olexkuroßggmail.com
}

Цель статьи - определить и проанализировать основные типологические блоки игрового репертуара традиционной украинской свадьбы в завершающей - перезвянско-карнавальной части, где ведущая роль принадлежала представителям взрослой половозрелой группе населения. Методология. Исследование проведено на основе междисциплинарного подхода, путем системного анализа литературных, документальных, этнографических и фольклорных материалов. Научная новизна. Проведенное исследование восполняет существенный пробел в изучении развлекательно-игровой культуры украинцев. Выводы. Преимущественно аграрный характер традиционной культуры украинцев объясняет тот факт, что главный массив репертуара перезвянской (второй) части народной свадьбы составляют игровые практики, которые имитируют производственную деятельность земледельца. В контексте архаического сознания трудовые процессы тесно ассоциировались с продуктивно-эротической магией, призванной обеспечить счастье и благополучие новой семьи. Игры с ярко выраженной эротической символикой и атрибутикой, сопровождаемые соромицким фольклором и экспрессивной лексикой, принадлежат к древнейшему пласту аграрной обрядности. В традиционном свадебном поезде украинцев эту группу представляют игры «Толочь ступу», «Забивать кол» («Чоп»), «Показывать границу» и другие. K категории имитационных принадлежат игры: «Молотить рожь» или «Сеять рожь», «Косарь», «Кузнец», «Мельник», «Токарь», «Молотилка», «Комбайн» и другие.

\section{GAME REPERTOIRE OF TRADITIONAL WEDDING OF UKRAINIANS}

\author{
Oleksandr Kurochkin, \\ Doctor of Sciences (History), Professor, \\ Kyiv National University \\ of Culture and Arts, \\ Kyiv, Ukraine, \\ https://orcid.org/0000-0002-3365-7266, \\ olexkurodgmail.com
}

The purpose of the article is to analyze and determine the main typological blocks of the game repertoire of the traditional Ukrainian wedding in its final namely Perezviansk-carnival part, where the leading role belonged to the adult sex and age group. Methodology. The study was conducted based on an interdisciplinary approach, through a systematic analysis of literary, documentary, ethnographic and folklore materials. Scientific novelty. The study fills a significant gap in the study of entertainment and gaming culture of Ukrainians. Conclusions. The predominantly agrarian nature of the traditional culture of Ukrainians is explained by the fact that the main array of the repertoire of the Perezvian (second) part of the folk wedding consists of game practices that mimic the production activities of the farmer. In the context of archaic consciousness, labour processes were closely associated with productive erotic magic, designed to ensure the happiness and well-being of the newly formed family. Games with pronounced erotic symbolism and attributes, accompanied by shameful folklore and expressive vocabulary, belong to the oldest layer of agrarian rituals. In the traditional Perezvian (second) part of Ukrainian wedding, this group is represented by the games "Pestling in Stupa", "Hammering a Stake" ("Peg"), "Show the Boundary" and others. The category of imitation games includes: "Threshing rye" or "Sowing rye", "Mower", "Blacksmith", "Miller", "Turner", "Thresher", "Combine" and others. The method of game undressing (exposure) observed by us in the wedding custom is the antithesis of carnival dressing and disguise. Both of these game practices are traditional 
Наблюдаемый нами в свадебной обрядности прием игрового раздевания (обнажения) является антитезой карнавального наряжания и маскировки. Обе эти игровые практики выступают традиционными способами переноса людей в атмосферу праздника, где все «вверх дном», не так, как в повседневной жизни. Историческая эволюция свадебных обрядов шла разными путями: наиболее варварские и архаичные отмирали, а другие постепенно превратились в народный самодеятельный театр, характерными признаками которого выступают юмор, жизненный оптимизм, драматическая импровизация.

Ключевые слова: свадьба; обряд; игра; традиционные развлечения; эротический фольклор; народный юмор; праздничный доcyz. ways of transferring people into a festive atmosphere, where everything is "upside-down", not as in everyday life. The historical evolution of wedding ceremonies went in different directions: the most barbaric and archaic died out, and others gradually became a folk amateur theatre, characterized by humour, optimism, dramatic improvisation.

Keywords: wedding; ritual; game; traditional entertainment; erotic folklore; folk humor; festive leisure.

Актуальність теми дослідження. Сьогодні помітно зростає інтерес науковців різного профілю до вивчення національних культурно-дозвіллєвих практик святкової комунікації. Зручним робочим інструментом аналізу цієї проблематики є концепт «гра». Ігрове начало - одне з найбільш значимих в історії цивілізації. Як архитиповий вид людської діяльності гра $є$ одночасно раціональною у своїх виявах та іраціональною у своїй суті. За визначенням Йогана Гейзінги (1994), «гра не входить до антитези мудрості й глупоти, і так само далека вона й від пар істина та омана, добра і зла. Хоч вона не матеріальна, духовна категорія, але не несе в собі ніякої моральної функції, так і цінності як гріх і доброчесність, не прикладаються до неї (с. 13).

Генезис гри тісно пов'язаний з генезисом ритуально-магічних практик. «Священодійство, на думку Й. Гейзінги (1994), має всі формальні й суттєві ознаки гри» (с. 26). У святкових та обрядових діях завжди присутня ігрова стихія, і тому ці феномени культури правомірно розглядати крізь призму ігрової концепції.

Аналіз останніх досліджень і публікацій. Кожен етнос упродовж століть формував свій арсенал ігрових традицій і форм, тісно пов'язаний 3 його історією, особливостями побуту, сімейного й громадського життя. Однак доводиться констатувати, що вітчизняна етнологічна наука не приділяла належної уваги вивченню ігрової культури українців. Ця галузь духовної життєдіяльності народу висвітлювалася в наукових виданнях фрагментарно й нерегулярно. Зміст ігор найчастіше залишався без інтерпретації або коментувався поверхово. Протягом другої половини XIX - початку XX ст. зусиллями таких відомих народознавців, як К. Сементовський, М. Сумцов, П. Іванов, В. Милорадович, З. Кузеля, В. Гнатюк та ін., були зібрані цікаві відомості про ігровий репертуар дітей та молоді з різних регіонів України. Проте ці емпіричні факти спеціально не досліджувалися і не 
аналізувалися в плані їх походження і впливу на різні сфери життєдіяльності традиційного суспільства. Значні проблеми у вивченні вітчизняної ігрової культури не ліквідовані й досі. Реальний стан речей у цій сфері спонукав сучасного історіографа В. Старкова (2009) зробити невтішний висновок: «Ігровий досвід українців не узагальнений, корпус українських ігор не опублікований, відсутня класифікація ігор за прийнятою системою» (с. 100).

Тривалий час поза увагою вітчизняних етнологів залишалися ігрові практики дорослого населення України, зокрема яскраве ігрове розмаїття традиційного весілля, хоча окремі ігрові епізоди вряди-годи згадувалися в загальному обрядовому сценарії, але не отримували фахової оцінки.

Суттєвою перепоною на шляху дослідження традиційних весільних ігор був їхній безпосередній зв'язок зі сферою ритуальної еротики і соромітчиною. Академічна наука свідомо ігнорувала ці питання через потрійне табу: церковної, політичної і моральної цензури. Такий стан речей, як зазначав Хв. Вовк (1995), був обумовлений, з одного боку, «соромливістю етнографів», а 3 другого - «суворістю російської цензури» (с. 302). Названі причини були оприлюднені на сторінках французького журналу «L’Antropologie» 1891 р., але фактично вони не втратили своєї актуальності й для наступної історичної доби. Так, у 20-х роках XX ст. академік М. Грушевський (1993), солідаризуючись із Хв. Вовком, мусив визнати, що значними перепонами в дослідженні оргіастично-ігрового елементу весілля «ставали і цензурно-поліційні заборони, і власна прюдерія збирачів» (с. 276).

Ситуація не змінилася на краще і в радянські часи, коли вже комуністичною цензурою, з ідейних міркувань, послідовно замовчувався та елімінувався еротично-ігровий пласт народної звичаєвості й фольклору.

Лише в останні десятиліття, в умовах демократизації вітчизняного суспільства й науки, намітилися певні зрушення у висвітленні раніше табуйованих аспектів народного життя й культури. Посильний внесок у розкриття обговорюваної проблеми здійснив автор цих рядків (Курочкін, 2004, 2015, 2016a, 2016b, 2019).

Проблема типології й систематизації такого складного за формою і за змістом матеріалу, як ігрова діяльність, ще далека від остаточного вирішення. Сучасна наука не знає загальноприйнятої та єдиної типології ігор і віддає перевагу «так званим штучним класифікаціям, в основу яких покладається довільно обрана ознака, що має значення з практичної точки зору для цілей здійснюваного дослідження» (Панеш \& Ермолов, 2000, с. 11).

На широкому порівняльному матеріалі слов’янських народів традиційні ігри охарактеризовані в статті I. Морозова (1999), вміщеній у 2 томі енциклопедичного видання «Славянские древности». Запропонована дослідником класифікація ігрових практик почасти використовується в нашій розвідці.

Мета статті - проаналізувати і визначити основні типологічні блоки ігрового репертуару традиційного українського весілля у його завершальній - перезвянсько-карнавальній частині, де провідна роль належала представникам дорослої статево-вікової групи населення.

Матеріалом для нашого дослідження послужили наукові публікації, архівні дані, а також результати польових етнографічних експедицій останніх десятиліть, здійснені співробітниками Інституту мистецтвознавства, етнології та фольклористики ім. М. Рильського НАН України. 
Виклад основного матеріалу. Для з'ясування генезису й сутності весільних обрядових ігор важливі пам'ятки середньовічної літератури. Вони не містять конкретної інформації про зміст і репертуар давньоруських забав, але виразно характеризують світоглядні основи цього пласту народної культури. Представники церковних кіл послідовно засуджували «ігрища бісовські» в одному ряду з музикою, співом, танцями, личинами, «срамословієм», скоморохами та іншими тяжкими гріхами, вважаючи їх спадщиною язичництва. Характерні слова з повчання митрополита Даніїла, який писав: «Идбже есть играніа, тамо есть діавол, а идбже есть плясаніе, тамо есть сатана» (Успенский, 1996, с. 16).

Особливий інтерес для нашої теми становлять церковні повчання проти «безсоромних», «непристойних», «богомерзьких», «грубих» ігор і танців у народній звичаєвості, зокрема весільній. За ними ховається не лише ворожість до традицій поганської релігії, а й загострене аскетичною мораллю християнства почуття відрази до всього сексуального, плотського.

Ігри з яскраво вираженою еротичною символікою й атрибутикою, супроводжувані сороміцьким фольклором та експресивною фразеологією, належить до найдавнішого пласту землеробської обрядовості. Вони концентрувалися в рамках перезви - епілогу весілля, який, за спостереженнями М. Грушевського (1993), «доходив часами незвичайної «непристойності», так що перед нею ... спинялась рука найбільш пильних збирачів пам’яток словесної творчості» (с. 277).

Показовий приклад - весільна гра «товкти ступу» не раз фіксована переважно на Правобережному Поліссі. Сороміцький фольклор конкретно і чітко характеризує семантику ступи. Традиційне знаряддя для подрібнювання зерна на крупу чи фураж у ритуально-міфологічному (алегоричному) контексті виступає символом нареченої, жінки взагалі й жіночого дітородного органу. Відповідно як чоловічий символ - фалус - трактується дерев’яний товкач - (пест, ступак тощо). Повертаючись із нареченою в дім молодого, співали:

Тупу, коники, тупу!

То везем - же ми ступу,

Хто буде в цю ступу пихати -

Та той буде користь мати...

(Кримський, 2009, с. 154).

У поліському варіанті пісні семантика знаряддя для переробки зерна набуває більшої конкретизації:

Тупу, коники, тупу

Везем ступу.

То не ступа, то колодиця,

То не дівка, то молодиця

(Польові матеріали I. Несен 2000 р.,

с. Мелені, Коростенського р-ну

Житомирської обл.). 
Тепер співставимо вербальний рівень ритуалу з акціональним. На північній околиці Київського Полісся, у зоні теперішнього Чорнобильського відселення, нами зафіксована присутність ступи в сороміцькій грі «вінчання батьків», яка припадала на третій день весілля. Головних учасників карнавального дійства переодягали за принципом - навпаки, з гротескним підкресленням ознак протилежної статі: батька вбирали в жіночий одяг (бюстгальтер, панчохи, спідниця тощо), мати - у чоловічий (штани, майка, кашкет тощо), між ніг її чіпляли моркву чи буряк. Спеціальні шати у вигляді накинутого на голову рядна чи простирала мала й сваха, яка виконувала роль попа. Сміхова церемонія полягала в тому, що «молодих» під музику (гармошка, бубон і кларнет («дудка») водили навколо ступи, у якій «піп» старанно товк воду ( чи не звідси фразеологізм: «товкти воду в ступі»?). Одночасно присутні обливали водою карнавальну шлюбну пару. «Вінчання» супроводжувалося непристойними словами - «матюками». Наприкінці обрядової гри батьків урочисто вкладали в ліжко, і «тоді вже буває сміху», як повідомляли інформатори (Польові матеріали автора 1995 р., с. Андріївка Чорнобильського p-ну Київської обл.). Маємо відомості, що на Черкащині, «дуріючи» на весіллі, ступу товкли на хаті (Польові матеріали автора, 1987 р., с. Драбівка Корсунь-Шевченківського р-ну Черкаської обл.).

Знаючи вербальну семантику ступи, навряд чи помилимося, добачаючи в акціональному тексті ігор з цим предметом варіант символічного зображення статевого акту - coitus’a. Кощунне наслідування (фарсове перевертання) церковного вінчання в такій редакції виглядає як середньовічна «раrodia sacra».

До архаїчних рудиментів язичницького світогляду варто віднести й весільну оргіастичну гру «забивання кілка (чопа)», зафіксовану нами на території Житомирської, Київської, Черкаської, Полтавської, Донецької областей. Гра відбувається в перший або другий день після шлюбної ночі, здебільшого в тих випадках, коли батьки женять або віддають заміж останню дитину. Забивання кілка (в деяких місцевостях вживається синонімічна лексема «чіп») проходить у святково-сміховій атмосфері. Активними учасниками гри - «молотобійцями»- виступають усі присутні, в першу чергу охочі до забави чоловіки, нерідко вони в чудернацькому вбранні, тобто належать до гурту весільних ряджених.

Зібрані відомості дають підстави прояснити деякі істотні деталі. Сам кіл (чіп) це дебелий шматок дерева, заструганий з одного боку довжиною близько метра. За давнім звичаєм його забивають на сакральній межі - із середини хати біля порогу в земляну долівку. Коли почали стелити дерев'яні підлоги, весільний кіл стали забивати біля порогу хати ззовні, на дворі. Ще пізніше, у зв'язку з традицією асфальтувати двір , гра переноситься на зручний майданчик біля воріт.

Процедура забивання є трудомісткою і може тривати кілька годин. Перед початком гри кіл прикрашають червоною стрічкою. Об нього розбивають і тарілку, і чарку горілки «на щастя». Подекуди під кілок підкидають ганчірку, в яку загорнуті гроші. Вони дістаються тому, кому вдається його витягти. Щоб полегшити роботу, землю навколо чопа поливають водою, розколоченою з попелом. При цьому ряджені молотобійці час від часу вигукують: «кіл сухий не лізе». Щоб підтримати сили учасників гри, господарі неодноразово пригощають їх горілкою. У калюжі, яка створюється від частих поливань біля кілка, весільні гості стрибають і танцюють, намагаючись обляпати одне одного брудом: чим більше - тим краще й ве- 
селіше. Очевидно, тут спрацьовує архаїчний поведінковий механізм зараження: пригадаймо, як люблять бавитися в грязюці діти. «Прикілкові» танці обов’язково супроводжуються жартівливо-обсценними піснями і примовками, але тексти ці інформатори згадують дуже важко й неохоче, соромлячись при цьому. Наприклад:

Поза гаєм, гаєм штанці поскидаєм -

Ти на мене, я на тебе: вродє віддихаєм.

Ой ти Галю, зроблю тобі лялю,

Будеш колихати, мене споминати...

(Польові матеріали автора, 2001 р.,

с. Савинці Миргородського р-ну

Полтавської обл.).

Цікаво, що самі інформатори називають такі співанки «стидними», «дурницями», які доречні лише в атмосфері весільного бешкетування.

Досліджувана весільна гра прямо кореспондує з магічною практикою, за допомогою якої дівчата приваблювали до себе хлопців, організуючи осінньо-зимові вечорниці й весняно-літні «вулиці». «Як починаються веснянки, - зазначає Б. Грінченко (1899), - то перший раз варять горщик каші, виносять на вулицю, закопують і пробивають його кілком. Оце до цього звичаю і пісня:

\section{Закопали горщик каші \\ Ще й кілком прибили. \\ Щоб на нашу та улицю \\ Парубки ходили» (с. 56).}

Отже, у словесному та ігровому фольклорному контексті кілок виступає як уособлення молодого чоловічого статевого органу. Ми схильні вбачати в описаній вище весільній грі пережитки давньої космологічної схеми ієрогамії, яка втілювала в ритуалі поєднання двох світів - верхнього і нижнього, двох протилежних принципів жіночого й чоловічого. На ідеологічному рівні гра пов’язана $з$ давніми міфологічними уявленнями про колективний шлюб громади чоловіків з Матір’ю - Землею, яка повинна була завагітніти і дати новий плід (Курочкін, 2004, с. 51).

Примітивний еротизм архаїчних перезвянських розваг виразно характеризують ігрові ситуації з демонстрацією оголеного тіла. Це суто карнавальні форми, елементи народної сміхової культури. Заглибитись у проблематику дають змогу етнографічні матеріали, які наприкінці XIX ст. збирала на Чернігівщині П. Литвинова-Бартош. Узявши на озброєння критерій моральної оцінки, вона запропонувала розмежувати весільні ігрища на «чемні» й «нечемні» (Литвинова-Бартош, 1900, c. 169).

На жаль, маємо лише один опис гри другої категорії. П. Литвинова-Бартош (1900) свідчить: «...роблять смотр молодицям, так на пр.: повісять на дверях гойдачку «горелі» і посадивши або поставивши на них молодицю чоловіки розгойдують вужівки, аби плахта й сорочка задубилась заголивши нижню частину тіла, а самі оглядають і т.і.» (с. 169). 
Враховуючи ту обставину, що в традиційному селі жінки не носили нижньої білизни, наведену гру можна трактувати як вульгарний народний стриптиз. Але, на відміну від сучасного комерційного стриптизу, споглядання тілесного низу в конкретній ситуації не є виявом естетичного або хворобливого цинізму, а сміховим прийомом, що маніфестує повалення традиційних етикетних норм в умовах карнавального інобуття.

Зрозуміло, що в сучасних умовах гра «строїти молодиць» вже не практикується. Але сміховий прийом оголення тіла в перезв'янських розвагах, за нашими даними, подекуди ще має місце. Майже до наших днів дожила обрядова гра «показувати межу». Зміст іiї полягав у тому, що хтось 3 підпилих гостей (найчастіше якась моторна сваха), заголивши зад, рачки обходила кордон городу, показуючи невістці місце її майбутньої праці в господарстві свекрухи. 3 певними застереженнями цю практику можна віднести до ігор дидактичного типу.

До описаної вище тематично близька розвага «ушивати хату», не раз задокументована нами на теренах Середнього Подніпров’я. У компанії бенкетуючих перезв’ян нерідко знаходився ентузіаст (чоловік або жінка), який, заголившись, вилазив на дах й удавав рухами, що укладає солом'яну покрівлю. Імпровізована вистава викликала загальний регіт і винагороджувалася додатковим могоричем з боку господарів (Польові матеріали автора, 1990 р., с. Лебедівка Кам’янського p-ну Черкаської обл.). І в даному разі маємо справу з побутовим реліктом архаїчного українського села, з його солом'яними стріхами, невибагливими формами дозвілля. Ще раз переконуємося, що духовна культура більш консервативна, ніж матеріальна.

Історична еволюція весільних обрядів, що тривала багато століть, відбувалася різними шляхами. Одні з них - найбільш варварські та архаїчні, увійшовши в протиріччя з новими умовами життя, відмирали й забувалися. Так, відійшли в минуле звичаї викрадання нареченої, триразового обходу молодим діжі біля порогу хати, заміна молодого дружком в обряді комора, зустрічі зятя тещею у вивернутому кожусі тощо.

Порівняно недавно із сільського побуту відійшов звичай публічної демонстрації «калини» - закривавленої сорочки молодої після першої шлюбної ночі. На Звенигородщині, за даними наших кореспондентів, у 60-х роках минулого століття перестали робити «маяки» - вивішувати публічно сорочку молодої з ознаками дівоцтва.

Важливі відомості щодо редукції весільного ритуалу в південній частині Нiжинського повіту на початку XX ст. зібрав знаний маляр і етнограф I. Павловський. За його матеріалами, у досліджуваний період практично зник звичай встановлювати «непристойні фігури» із соломи під час перезви, обдирати стіни хати й комина залізними вилами, записуючи хто що подарував, і прикладати «печатку» до цього запису.

I. Павловський (1926) констатував також, що майже повністю перервалася весільна традиція «зносити стіл на хату». Останній раз він спостерігав цей звичай у с. Дорогинці 1908 р. та в с. Томашівці 1919 р. Вражаюча бідність українського села (відсутність достатньої кількості їжі), на думку дослідника, була причиною того, що виходили з ужитку звичаї «купати весільну матір», забивати чопа та ін. Це ж стосується і звичаю «циганщини», який мав зникнути, «...бо зараз, - відзна- 
чає I. Павловський, - «циганам» майже ніхто не дає, а дуже часто так просто й 3 хати вигонять». Хронологічно марковані етнографічні дані I. Павловського можуть служити певним рівнем відліку. Крім того, слід відзначити помічену дослідниками пряму залежність стану функціонування звичаїв та обрядів від загального стану добробуту суспільства.

Паралельно 3 процесами редукції і природного відмирання традиційної весільної обрядовості йшов процес її перекодування й трансформації. Значна частина ритуальних форм, які виконували в минулому важливу магічно-сакральну функцію, перетворилися на усталені традицією ігри й розваги. Недарма поведінку учасників цих забав респонденти, як правило, характеризують у знижувальному плані: «чудять», «дуріють», «бешкетують», «фіглюють», «блазнюють», «штукарствують», «строять комедію» тощо.

«Просторове відокремлення ігрової діяльності від повсякденного життя» Г. Гейзінга (1994, с. 27) визнавав однією з найважливіших ознак гри. В умовах традиційного весілля святковим простором за формою і функціями могли служити селянська хата, подвір'я, вулиця, місцина біля річки або колодязя. У середині цього простору, за спільною згодою, створюється особлива атмосфера психологічної ейфорії, де можна і потрібно жартувати й веселитися. Кордони ігрового простору демаркуються в різний спосіб. У багатьох місцевостях України весільне подвір’я на час перезви стає, зокрема, химерною перукарнею. Ще зранку на воротях вивішують повідомлення з правилами поводженнями й відповідними тарифами:

Працює перукарня

$\begin{array}{ll}\text { 3 6-ї до 7-ї години } & -1 \text { крб } \\ \text { 7-a-8-a } & -2 \text { крб } \\ \text { 8-a-9-a } & -3 \text { крб } \\ \text { 9-a-10-а } & -5 \text { крб } \\ 310-о і ̈ & -10 \text { крб }\end{array}$

Таким чином тарифи стимулюють гостей збиратися раніше. Той, хто відмовляється платити за вхід, стає жертвою гротескного перукарського сервісу. Чоловіків намагаються поголити, використовуючи дерев'яну бритву великого розміру й віник замість помазка. До послуг жінок косметичні процедури і макіяж сажею й соком червоного буряка. Пропонують також цілувати закіптюжену сковорідку або заслінку від печі (Польові матеріали Ксензова В. С., 1987 р., с. Червона Слобода Черкаського p-ну і обл.).

У деяких областях України, де в пам'яті людей свіжі неприємні спомини про спалахи епідемії холери, свинячого та курячого грипу тощо, ігровий простір може трансформуватися в імпровізовану санепідем станцію. Ряджені лікарі й медсестри в білих халатах і масках удають, що дезинфікують прибулих гостей, роблять їм профілактичні щеплення, вимірюють тиск і температуру та ін. Заради сміху при цьому нерідко використовують медичний інструментарій ветеринарів, добре відомий учасникам карнавального дійства. Поруч з «офіційними» медиками в ньому можуть «практикувати» й народні цілителі. Знайшовши вдячного пацієнта, знахар ставить йому на живіт макітру або горщик, підкуривши їх попередньо віхтем конопель. При цьому виголошуються магічні формули й заклинання. Ця 
ігрова мізансцена пародійно відтворює прийом лікування «сояшниці» (спазматичних болей шлунку), яким здавна користувалися знахарі (Польові матеріали автора, 1987 р., с. Остап’є Великобагачанського р-ну Полтавської обл.).

Характерною ознакою ігрового весільного простору є присутність у ньому маскованих персонажів. Крім «перукарів» $\mathrm{i}$ «лікарів», особливою популярністю користуються ряджені «цигани». Вони головні заводії у створенні атмосфери карнавального хаосу і веселих безчинств. Весільні «цигани» зазвичай відтворюють у ігровій формі закріплені в народних уявленнях стереотипи поведінки справжніх ромів. Убравшись у якесь дрантя й намастивши обличчя сажею, вони галасують, жебракують, ворожать на картах і по руці, крадуть, що попаде під рукою, особливо курей тощо. Заради відтворення певного колориту ряджені можуть з'явитися на весіллі в циганському возі з шатром й виконувати пісні на зразок:

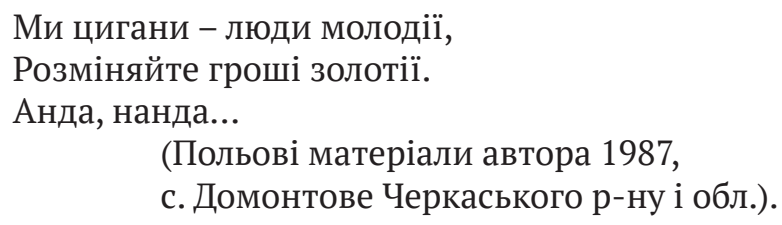

Етнокультурний феномен весільної «циганщини» детально проаналізований нами в спеціальній публікації.

Традиційне народне весілля - слушна нагода колективно «пити і гуляти». Алкогольні напої здавна супроводжували шлюбні церемонії українців. У давньоруську добу це були пиво й мед, пізніше до них додалися вино, горілка й самогон. Запастися необхідною кількістю спиртного - важлива турбота організаторів застілля. «Старий Джеря, - зазначає І. Нечуй-Левицький (1965), - й собі готувався до весілля. Він купив десять відер горілки, вісім відер взяв у жида за готові гроші, а дві відрі узяв на борг» (с. 49).

Частування спиртним супроводжувало всі головні акти весільного ритуалу, набувши свого апогею в умовах перезвянської оргії. Цю закономірність підтверджують народні пісні:

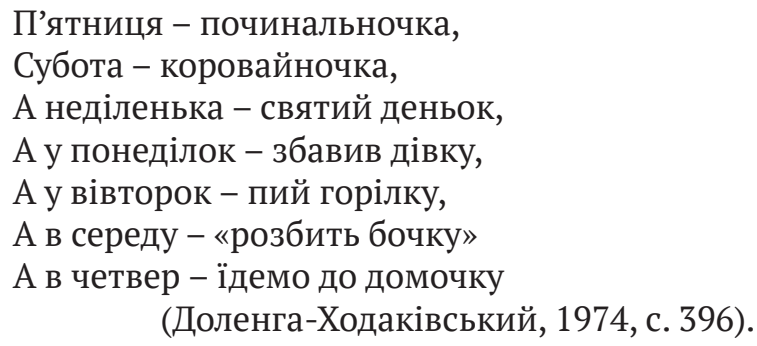

Повторюваний у багатьох весільних піснях мотив горілки знаходив предметну реалізацію в ігровій програмі перезви. Ілюстрацією може слугувати гра «Барило», відома в кількох локальних варіантах. Барило - невелика дерев'яна діжка, розрахована на 2-3 відра рідини. Його використовували зазвичай для зберігання холодної води під час жнив або косовиці. Барило як ємність алкогольних напоїв 
неодноразово згадується в українському фольклорі та літературі: «Вина з Царгороду відер троє»..., «Ой, піду ж я в комірчину, та загляну в барилчину» (Грінченко, 1958, с. 30).

Один з варіантів гри «Барило» був записаний нами в с. Романівка Попельнянського р-ну Житомирської обл., на батьківщині Максима Рильського. За даними місцевих респондентів (Бескаль А. Н., 1919 р. н. і Чуприни А. А., 1921 р. н.) гра була своєрідною перепусткою для гостей, які приходили до хати, де справляли весілля на другий або третій день. Барило, наповнене горілкою чи самогоном, підвішували в прорізі дверей, i кожен (кожна) мали випити з нього. «Як не хлюпнеш 3 того барильця, - згадувала А.Чуприна, - не посадять тебе за стіл, а там самогон. Заради більшого комічного ефекту поруч з діжкою підвішували й закуску - сиру моркву, капусту, цибулю. У тій же Романівці на Житомирщині вдалося зафіксувати фрагменти весільної пісні про барило, що засвідчує давність традиції:

\author{
I \\ А в нашого Йосипа, Йосипа \\ По припечку просо розсипалося \\ Горілочка із барилочки \\ Та й полилася... \\ II \\ Горілочка в барилочку \\ Як ми її не вип'ємо, \\ Звідси не вийдемо... \\ (Повний текст записати не вдалося)
}

Останнім часом, як засвідчили ті ж інформатори, замість барила, що виходить з ужитку, у дверях підвішують графин з вином чи горілкою. Отже, сама гра зберігається, без атрибута, який дав їй назву (Польові матеріали автора, 2007 р., с. Романівка Попелянського р-ну Житомирської обл.).

У деяких селах північної Київщини гра «Барило» проходила за іншим сценарієм. Діжку зі спиртним тут розташовували на столі, до якого приставляли драбину. Учасники перезвянської гостини по черзі вилазили нею вгору, щоб почастуватися з барила дерев'яною ложкою. Зграбно виконати цю фізичну вправу вдавалося не всім, особливо коли вона здійснювалася кілька разів. Динамічна гра неодмінно супроводжувалася жартами і сміхом (Польові матеріали автора, 1994 р., с. Мигалки Бородянського р-ну Київської обл.). Подекуди барило зі спиртним встановлювали на візку, коли на 2 або 3 день весілля везли батьків, які одружили останню дитину, до магазину, де купували їм жартівливі подарунки. Дорогою пригощали тих, хто виконував функції «коней» і всіх стрічних односельців. Локальна назва цього звичаю - «барило качати» (Польові матеріали автора, 1987 р., с. Маньківка Бородянського р-ну Київської обл.).

У весільних розвагах, як і в народних казках, присутній мотив викрадення і знаходження. До наших днів користується популярністю ігрова практика, коли викрадають коровай, молоду, черевичок з їі ноги. Все викрадене в ритуальному контексті повертається за певний викуп. 
Щоб урізноманітнити розважальну програму весільного дійства, господарі нерідко готують для гостей якісь сюрпризи. Свекруха, наприклад, може привселюдно заявити, що вона закопала в дворі «безцінний скарб», який дістанеться тому, хто його знайде.

Веселе товариство охоче включається в цю гру. Зять під схвальні вигуки глядачів копає землю в різних місцях подвір'я, аж доки (за підказкою нареченої) знаходить потрібне місце. Прихованим скарбом виявляється щільно запечатана діжечка із бражкою. Знахідку зустрічають радісними вигуками й оплесками, після чого діжку виставляють на стіл для колективного почастунку. У с. Балико-Щученка (Кагарлицького р-ну Київської обл.) вдалося записати фрагмент пісні, що супроводжувала цю розвагу:

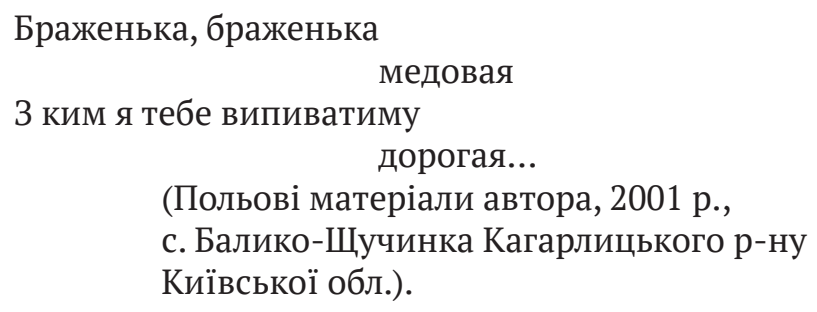

Із чарівних казок, вірогідно, у весільний ритуал перейшов ігровий сюжет «вгадай наречену». Описуючи весілля в с. Іспас під Коломиєю, О. Кольберг (Kolberg, 1962) свідчить: «Потім, коли князю загадано вийти з хати, сідають дві баби разом 3 княгинею на ослін і накриваються простирадлом (скатертиною). Здійснивши то, приводять знову князя і загадують йому вгадувать, котра з них є його жона. Якщо не вгадає, то повинен іï викупити; якщо вгадає, закінчується та сцена взаємними поцілунками молодят» (с. 310).

Подаючи вищенаведений опис, О. Кольберг (Kolberg, 1962) навів цікавий порівняльний фрагмент весільної гри із провінції Беррі (Франція). Тут молодий мав вгадати свою обраницю, споглядаючи лише відкриті литки і стопи ряду жінок, які для цього іспиту знімали з себе черевики й панчохи. Співставляючи обидві ігрові практики, мимоволі доходимо висновку, що галантні французи ще до шлюбу мали добре вивчити фізичні характеристики своїх майбутніх дружин.

У репертуарі перезвянських розваг традиційного українського весілля переважали ігри імітаційного типу, які відтворювали різні процеси трудової діяльності. Природно, що об’єктом зображення служили, насамперед, узвичаєні практики річного хліборобського циклу. Раніше вони мали магічну мотивацію, але з часом перетворилися на стереотипні розважальні обрядові форми поведінки.

Особливої уваги заслуговує весільна гра «молотити жито» або «сіяти жито». Ïї побутування досліджене в більшості областей північної і центральної України. Жито - сакральна хлібна культура українців, від якої безпосередньо залежав їхній добробут. Жито й життя - однокореневі поняття, і тому саме жито й усі ігрові практики, пов'язані з ним, у весільному ритуалі виступають запорукою - талісманом щасливого шлюбу. За традицією житом мати обсипала поїзд молодого, благославляючи в дорогу до нареченої. Готуючись до весілля, як правило, у суботу до хати обох молодят заносили житній сніп і встановлювали його на покуті як при- 
красу святкового інтер'єру. Активна фаза використання цього ритуального атрибуту припадала на час перезви. Гра «молотити жито» відома в багатьох локальних варіантах. Як і інші весільні розваги, вона не знала строгих правил і будувалася на імпровізації виконавців.

Найпростіший редукований сценарій гри полягав у тому, що житній сніп знімали з покуття, клали на підлогу і вдаряли кілька разів палицею, імітуваючи процес його обмолоту. Цей акт можна визначити як обрядовий мінімум.

Натомість розгорнуті сценарії гри передбачали символічне відтворення не однієї, а кількох виробничих операцій та збільшення кількості задіяних осіб. Наприклад, у с. Кошів (Тетіївський р-н, Київської обл.) ігрове дійство проходило в такій послідовності: у понеділок весільні гості (переважно чоловіки) молотили жито ціпами на городі й сіяли. Потім, озброївшись бороною й граблями, удавали, що боронять і заволочують посіяне. За даними респондентів, ці обрядові маніпуляції виконувалися незалежно від пори року, навіть і по снігу (Польові матеріали автора, 1987 р., с. Кошів, Тетіївського р-ну Київської обл).

За етнографічними матеріалами з Полтавщини, жито молотили на рядні, ставлячи поруч прядку або велосипед. Колеса цих пристроїв мали зображувати архаїчні жорна. На цьому ж рядні розбивали глиняний глечик і миску «на щастя». Черепки з обмолоченим житом збирали в мішок, «щоб не було пусте жито молодим». Обмолочену солому скручували у «віху», яку прив'язували стрічками до довгої палиці. Насамкінець - «вершили скирду» - закріплювали «віху» на вершині родючого дерева, яке росло поблизу хати (с. Велика Павлівка Зінківського р-ну Полтавської обл.) (Щербань \& Яреха, 2008, с. 61).

В іграх з імітацією сільськогосподарських процесів могли використовуватися відповідні фольклорні тексти. Так, співали:

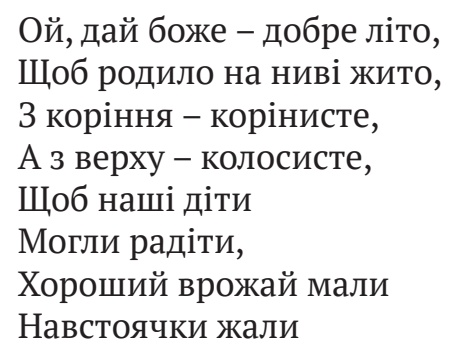

(Польові матеріали автора, 1987 р., с. Домонтове, Золотоношського р-ну Полтавської обл.).

Гра «молотити жито» подекуди закінчувалася тим, що учасники збирали розкидані на землі зерна й ділили їх між собою за допомогою наперстка. При цьому намагалися облити одне одного водою, бо, за словами респондентів «жито треба полити» (Польові матеріали С. Маховської, 2011 р., с. Річки Білопільського р-ну Сумської обл.). Важливо додати, що кожна ігрова акція її учасниками називалася «роботою», за яку господарі мали віддячити могоричем.

У традиційній культурі випробуваними засобами створення святкової реальності часто виступають сміх і гумор. Заради досягнення комічного ефекту в грі 
«молотити жито» вдало використовувався прийом інверсії, коли замість зерен на городі сіяли дрібну картоплю, боронували не бороною, а старим пеньком, волочили не граблями, а дебелою жінкою та ін.

Гумор - прикметна риса українського менталітету. У кожному конкретному випадку весільне ігрове дійство мало бути більш або менш розвинутим і розмаїтим. Істотну роль при цьому відігравав людський фактор, емоційна налаштованість і попередній досвід святкового товариства, наявність у ньому обдарованих артистичною вдачею осіб. Чудовий знавець культури і звичаєвості українського народу I. Нечуй-Левицький вважав національний гумор природженою рисою розуму і фантазії щирого українця. При цьому він розрізняв дві категорії штукарів і гумористів, перших «...оповідачів, що провадять свою розмову вперемішку 3 жартами, усякими приказками та прислів’ями, і таких людей, що виявляють свої жарти в дії в жартівливій міміці, в жвавих мигах руками й головою, в смішному передражнюванні своїх знайомих, в імпровізуванні цілих невеличких комічних сцен власної вигадки, в котрих вони удають людей як актори на сцені, удають будь-яку дієву особу в комедії...» (Нечуй-Левицький, 1966, с. 356).

У весільних забавах, позначених динамізмом та експресією, особливо цінуються гумористи другої категорії, здатні зосередити на собі увагу всього товариства. Виступаючи в будь-якій ролі, весільний скоморох свідомо наголошував свою унікальність за допомогою екстравагантних дій і атрибутів. Ілюстрацією може служити моноспектакль «Косар», задокументований 1986 р. фольклористом Т. Колотило в смт Білогір'я Хмельницького району й області. Ігрове дійство відбувалося в понеділок, коли родичі й сусіди зійшлися на фінальний акт весілля «відхідний борщ».

Коли гості зібралися за столами, на подвір'ї, як на сцені, з’явився провідний актор - «Косар», тягнучи за собою дідівські сани зі збіжжям. Кумедний образ цього персонажа маніфестувало його вбрання та екіпіровка. «Косар» був одягнений у старий військовий мундир, галіфе, на голові мав старосвітський капелюх. Одна нога взута у високий рибальський чобіт, а друга - у розірвану калошу. Походжаючи серед гостей 3 «Г»-подібною палицею, він імітував звичні при косінні рухи. Вказуючи на своє взуття, штукар голосно бідкався, розповідаючи, як заснув у полі, а злі люди відірвали в нього з чобота халяву. Підкреслено химерний одяг, жестикуляція і монолог актора немовби запрошували глядачів до подальшого розвитку самодіяльної вистави.

За деякий час «Косар» та інші охочі до забави гості гуртуються біля саней зі збіжжям, де стирчить великий необмолочений сніп жита. Його кладуть на землю (попередньо обсипану піском), i «Косар» своєю палицею, яка тепер виконує роль ціпа, молотить сніп. Ця робота супроводжується різними кумедними рухами, аби солома й бадилля розліталися на всі боки. Присутні весело коментують трудовий процес.

Завершивши молотьбу, на весільний кін запрошують молодих, щоб жартома випробувати їхню працездатність. Подружня пара мала зібрати всі розкидані на піску зерна, провіяти їх на вітрі і просіяти крізь сито. У такий спосіб імітаційна гра ставала одночасно дидактично-випробувальною. Коли скрупульозна робота завершувалася, хтось із присутніх обов’язково, ніби ненароком, перекидав посуд 
із зібраним зерном. Тепер молодим доводилося починати все спочатку, і так могло повторюватися кілька разів.

Зібране зерно демонстративно, з різними примовками й витівками зважують. У той же час добровільний «секретар» пише вугликом на стіні будинку жартівливий «документ», яким засвідчує зібраний урожай. У ньому названий «колгосп сорок років без врожаю», вказуються імена голови, бригадира, ланкової, кількість зібраних центнерів зерна з гектара тощо.

Пародійний звіт має завірити відповідна «печатка». Кілька чоловіків беруть «писаря» за руки і за ноги, садять його спочатку в шаплик, наповнений водою з розчиненою сажею, а потім, піднявши вгору, притискають задньою частиною тіла до стіни. Виконавши свою комедійну роль, самодіяльний актор переодягається і приєднується до загалу гостей.

Другий акт ігрового дійства в тому ж смт Білогір'я розпочався тоді, коли на воротях з'явилася комедійно прибрана весільна пара псевдомолодят у супроводі ряджених сватів, бояр, дружок та інших чинів. Як і в багатьох інших європейських народів, комічне подружжя витримане за певним карнавальним шаблоном: «молоду» зображує високий худорлявий чоловік, а «молодого» - невисока огрядної статури жінка. Характерні ознаки цих травестованих персонажів - яскравий грим і вульгарно наголошені статеві ознаки.

Ігрова поведінка фальшивих молодят полягає в тому, щоб активно демонструвати свої еротичні потяги: цілуватися, обійматися, імітувати любощі, явно переходячи кордони пристойності. Забави ряджених супроводжуються танцями, приспівками, біганиною, жартівливими сварками, що створює загальну атмосферу святкового хаосу (Польові матеріали Т. І. Колотило, 1986 р., смт Білогір'я Хмельницького р-ну і обл.).

Подаючи наведений матеріал, Т. Колотило зауважив цікаву деталь: хоча описане дійство зберегло давню назву - «відхідний борщ», але сама ця страва гостям вже не подавалася, що підтверджує процес редукції народних традицій.

У патріархальному українському селі, де носії інших професій, ніж власне хлібороби, складали абсолютну меншість, їх постаті та діяльність наділялися певними сакральними рисами і надприродними властивостями, характерними для представників «чужого світу». Образ ремісника транслював певний соціальний код, відображений у традиційній звичаєвості та фольклорі.

У багатьох місцевостях України ковальським ремеслом займалися представники ромської етнічної спільноти. Тому карнавальний образ цигана-коваля набув широкого розповсюдження. Зазвичай цей персонаж, озброївшись молотком та різними господарськими виробами із заліза, пропонує весільним гостям прибити підкову на взуття або виготовити якийсь необхідний інструмент: серп, косу, сапу тощо.

Так, у кримському селі Мазанка (Сімферопольський р-н) до завдання цього карнавального персонажа входило «підковувати» всіх гостей, що сходилися на другий або третій день весілля. За свою роботу «циган-коваль» збирав дрібні гроші, які йшли на жартівливі подарунки для батьків (Польові матеріали О. Соболевої, 2013 р., с. Мазанка Сімферопольського р-ну, Автономної Республіки Крим). Процедура «підковування» як символічна перепустка на весільний карнавал відома і в інших регіонах України. 
У гоголівських місцях на Полтавщині (с. Диканька, Мачуха) на весіллях серед інших ігор влаштовували «кузню». Для цього посеред двору підпалювали старий пень, з якого курився дим. Удавані «ковалі» пропонували всім гостям набити на взуття підкову та обмазати обличчя сажею. Від цієї послуги можна було відкупитися грошима або самогоном (Польові матеріали автора, 1987 р., с. Диканька, с. Мачухи Миргородського р-ну Полтавської обл.).

Слід наголосити, що присутність образу коваля у весільному ритуалі українців має глибокий міфологічний підтекст. За народними уявленнями, «божий коваль Кузьма Дем’ян», який переміг легендарного змія і запряг його в плуг, був одночасно покровителем шлюбних союзів. Фольклорні тексти дають змогу простежити прозорий асоціативний зв'язок ковальського ремесла зі статевим актом. Показовий уривок із сороміцької пісні: «коли коваль ковалисі ковалятко кує...» тощо.

Символічний зв’язок з еротичною магією простежуємо й у весільному карнавальному персонажі «Мельник», або «Мірошник». У народних піснях цей образ нерідко демонізується й романтизується, при цьому наголошується його схильність до любовних пригод. Життєва практика знала випадки, коли за обробіток збіжжя в млині жінка могла розплатитися не грошима, а «натурою». Це опосередковано підтверджує такий фольклорний текст:

$$
\begin{aligned}
& \text { Такий, мати, мельник добрий, } \\
& \text { Такий, мати, хороший, } \\
& \text { Меле гречку без грошей... } \\
& \text { (Вовк, 1995, с. 245). }
\end{aligned}
$$

Сам механічний процес рівномірного обертання жорен, коли із зерен жита або пшениці народжувалася нова якість - борошно, був близькою народній свідомості паралеллю - зародження й народження дитини чи статевої ініціації. Звідси прислів’я: «мука - 3 пшениці, з дівки - молодиця». Відомо, що в своїх «Поясненнях» О. Потебня порівнював символіку жнив з весіллям, а молотьбу зерна чи мелення крупи зі статевим актом, наводячи для прикладу фрагмент весільної пісні: «На печі молотив, на припічку віяв. Не кажи дівчинонька, що я тобі діяв» (Вовк, 1995, c. 245).

Явна й латентна еротична символіка дає себе знати в ігрових практиках перезви, що імітують механіку обмолоту. Гра під назвами «Млин», «Мельниця», «Молотарка», «Комбайн» відома в різних варіантах. У с. Соловіївка (Брусилівський p-н Житомирська обл.) вона побутувала під назвою «молотити зажон» (сніп - О. К.). Гра відбувається на третій день весілля, «на курах», коли веселі забави влаштовують ряджені «цигани». Хтось із гостей має спертись об стіл, і йому крізь ноги, немов у жорна млина, кидають оберемки колосся. Якщо батьки віддають до шлюбу останню дитину, їм виплітають із соломи вінки, а «зажон» встановлюють на покуті, прикрасивши квітами й цукерками (Польові матеріали автора 2008 р., с. Соловіївка Брусилівського р-ну Житомирської обл.).

У тій же поліській місцевості вдалося зафіксувати гру під назвою «Молотарка». Респондентка Осович С. Ю.,1931 р. н., розповіла: «Ставили два ослони, я стаю на ці два ослони рачки. Сюди під ослін пхають солому, а я ногами: тра-та-та-та. Молотарка молотить. Це машина така, що зерно молотила. А тоді вже така гульня 
була - таке молотіння...» (Польові матеріали автора 2008 р., с. Дивин Брусилівського р-ну Житомирської обл.).

Наївною еротикою позначена гра «Млин», записана нами в с. Остап’є (Великобагачанський р-н Полтавської обл.). У грі задіяні три актори. Дві жінки накриваються великим лантухом: одна старанно гуде, друга ритмічно дригає ногами, зображуючи обертання жорен. Хтось з чоловіків зображує діда-мірошника (борошном малює собі вуса). Розігрується сцена, начебто мірошник спить. Раптом здіймається буря і млин треба зупинити. Удаючи, що робить цю операцію, «мірошник» насправді лапає жінок під лантухом, що викликає їхній вереск і загальний регіт присутніх (Польові матеріали автора, 1987 р., с. Остап'є Великобагачанського р-ну Полтавської обл.).

Ремісничі сюжети весільних розваг презентує і гра «Токар», наведена в етнографічних матеріалах Б. Грінченка. За його даними, токарний станок будували на дворі з того, що потрапляло під руку: бочка, стілець, цебер тощо. Після того «винесуть колесо і закладуть його на великий дручок і такого чоловіка вибирають, що вміє штуки приставляти (Грінченко, 1899, с. 456).

Зробивши ряд маніпуляцій руками біля удаваного станка, які мали імітувати процес виготовлення дерев’яної ложки, «Токар» діставав її із пазухи і демонстрував як щойно виготовлену річ. У такий же артистичний спосіб «точилася» й тарілка. Традиційність гри підтверджує супровідна пісня. Свахи з боку молодого співали:

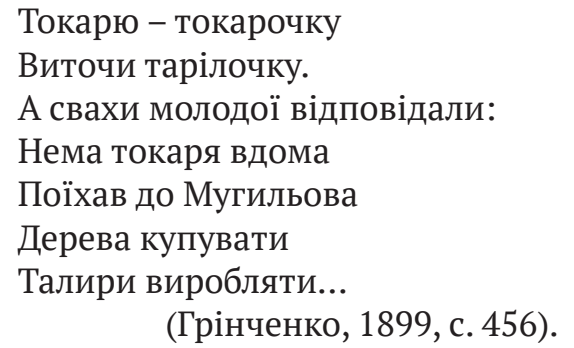

Організуючими домінантами весільних розваг поряд із самодіяльними акторами можуть виступати й окремі обрядові атрибути. Проілюструємо цю тезу на прикладі гри «Пекти гарбуз», описану нашим кореспондентом з Черкащини. Звичайна городня культура - гарбуз (кабак) у вульгарному побутовому мовленні пов'язана з еротичною семантикою, виступаючи одночасно алегоричним замінником чоловічих геніталій і атрибутом сватання зі знаком (-). Дівчина могла піднести гарбуза реально або фігурально небажаному залицяльнику, що вважалося образливою формою відмови (Курочкін, 2004, с. 11).

3 урахуванням зазначеного семантичного підтексту використання гарбуза у перезвянських розвагах, що моделюють світ антикультури, виглядає цілком доречним. Ігрова роль цього атрибута - бути пародійним двійником весільного короваю.

Ігрове дійство «пекти гарбуз», що за традицією відбувається на третій день весілля, відомий як «циганщина». Компанія ряджених садовить батьків молодої 
на візок, до якого чіпляють виплетений з конопель хвіст, і возять їх по селу з гучними вигуками, музикою й піснями.

Повернувшись із ритуальної мандрівки, веселе товариство розпалювало на дворі багаття, у якому й пекли гарбуз. Навколо вогню йде гульня: стрибають, танцюють, співають. Гарбуз має стерегти близький родич батьків, бо його можуть вкрасти. Якщо це комусь вдається, гарбуз, як і коровай, треба викупити. Коли згасає полум'я багаття, удаваних молодих, а насправді батьків, перевозять на возику через вогонь і обрізають виплетеного хвоста повністю, якщо віддали до шлюбу останню дитину, або наполовину, якщо є ще неодружені діти. У такий спосіб здійснюється колективна пародійна ініціація, що знаменує перехід до нового етапу соціальної зрілості конкретної родини.

Спечений гарбуз виконує роль основної ритуальної страви карнавально-сміхового бенкету. Його «крають», як і справжній весільний коровай. Цю операцію здійснюють чоловік і жінка, ріжучи повільно гарбуз дворучною пилою під пісню, якою супроводжують обряд розподілу короваю на справжньому весіллі. Коли ріжуть гарбуз, присутні кричать не «гірко», а «жарко». За кожним таким вигуком добровільні витівники мають зняти із себе якийсь елемент одягу. Як далеко заходить цей ритуальний стриптиз, інформатор не зазначив. Завершуючи забаву, шматочками гарбуза наділяють усіх учасників карнавального весілля, а його винуватців «скривають» великим рядном (Польові матеріали Ксензова В. С., 1987 р., с. Червона Слобода Черкаського р-ну і обл.).

3 ігрового арсеналу традиційного українського весілля можна виокремити групу танців-ігор, що проходили нерідко в супроводі музики й пісень. Чотири такі обрядові композиції, а саме - «Журавель», «Зайчик», «Танці на рядні», «Чоботи» проаналізовані нами раніше (Курочкін, 2019). Додамо до цього ряду ще дві позиції.

Гра «В нашого діда» записана нами на Подніпров’ї (с. Білозір’я Черкаського p-ну і обл.). На третій день весілля, що має назву «кури», після застілля гості виходять у двір і створюють велике коло. У його середину виходить «дід»-затійник, рухи і дії якого мають наслідувати всі учасники гри. «Дід» вимахує руками, задирає ноги, знімає з себе якусь частину одягу тощо. Тих, хто не встигає виконувати його команди, ведучий може покарати батогом (Польові матеріали автора, 1997 р., с. Білозір'я Черкаського р-ну і обл.).

Подібна гра-танець 3 елементами гумористичної еротики на Поділлі відома як парубоча «Роби те, що я». Довідуємося про правила цієї гри в с. Жабиня на Зборівщині за описом Петра Медведика (1996), зробленим у першій половині ХХ ст: «...гурт у складі 7-9 хлопців стають у ряд на віддалі руки, спертої на плече попередника і рухливо йдуть під мелодію музик за першим «ведучим», який держить у руках ремінець. Раптово виконує на ходу якийсь жест, який кожен учасник гри має швидко повторити: скидає піджак, викидає в сторону хусточку, знімає 3 якогось гостя капелюх і кладе на свою голову, роззуває одну ногу, витягує 3 кишені або знаходить на подвір'ї папірець і робить 3 нього папіроску, танцює на одній босій нозі, стає на руках і підносить ноги вгору, платить музикам гроші, кланяється із смішними видумками молодій, цілує дівчину, роздягається із светра, сорочки, майки... Якщо хтось вчасно не повторить того, що зробив «ведучий», то такий парубок одержує покарання ремінцем або дає викуп» (с. 65). 
Жартівливому характеру наведеної забави відповідали й супровідні приспівки-коломийки:

\author{
Ой не буду женитися \\ Аж за літ п’ятнадцять \\ Коли дівки потаніють* \\ Копійок на двадцять... \\ (Медведик, 1996, с. 73) \\ [“Потаніють - стануть дешевшими - О.К.] \\ Або:
}

Ой заграй ми музиченьку,

Дам ти яєць діжу.

Як не хочеш файно грати,

То твої відріжу...

(Медведик, 1996, с. 76).

Гра «Роби те, що я» на Південному Поділлі побутує в іншій редакції під назвою «Каперуша». У с. Печорна (Заліщицький р-н Тернопільської обл.) ії виконували на другий день весілля вже не парубки, а дорослі чоловіки. Утворивши коло, вони під музику слухняно наслідували команди старшого за віком, повторювали його вигадки й жести: стрибали на одній нозі, цілували жінок, роззувалися, скидали із себе одяг тощо. Усі пертурбації «Каперуші» уважно спостерігає і весело коментує жіноча аудиторія (Польові матеріали автора, 1981 р., с. Печорна Заліщицького р-ну Тернопільської обл.).

Припускаємо, що перехід раніше парубочої гри до забави дорослих чоловіків $\epsilon$ наслідком постійної редукції весільного ритуалу, яка простежується впродовж останніх десятиліть.

Спостережений нами в перезвянській звичаєвості прийом ігрового роздягання (заголення) $є$ антитезою карнавального рядження й маскування. Обидві ці ігрові практики є традиційними способами перенесення людей в атмосферу свята, де все «догори дригом», не так, як у буденному житті.

Наукова новизна. Проведене дослідження почасти заповнює істотну прогалину у вивченні розважально-ігрової культури українців. Тривалий час ця проблематика під впливом клерикальної, ідеологічної та моральної цензури залишалася поза увагою вітчизняних науковців.

Висновки. Зібрані й проаналізовані нами фольклорно-етнографічні матеріали дають певне уявлення про багатий ігровий репертуар другої - перезвянської частини народного весілля. Переважно аграрний характер традиційної культури українців пояснює той факт, що основний масив цього репертуару складають ігрові практики, котрі імітують виробничу діяльність хлібороба (від обробки землі та збирання врожаю до виготовлення харчових продуктів). У контексті архаїчної свідомості трудові процеси тісно асоціювались із продуктивно-еротичною магією, покликаною забезпечити щастя й добробут новоствореної сім'ї. 
Втрачаючи в ході історичної еволюції свою сакральну символіку й магічні функції, весільне обрядово-ігрове дійство поступово перетворилося на народний самодіяльний театр, характерними ознаками якого стали рядження, гумор, бешкетування, драматична імпровізація тощо.

Весільні обрядові ігри дорослої верстви населення мають синкретичний характер і не піддаються чіткій класифікації на імітаційні, ролеві, дидактичні та інші типи.

Із позиції сучасної освіченої людини розважально-ігрові практики традиційного весілля можуть сприйматися як наївні, примітивні й вульгарні. Але такий погляд позбавлений історичності й розуміння цінності культурних пережитків. Завдяки їм дрслідникам вдається здійснювати палеоетнографічні екскурси в минуле, вивчати джерела народного світогляду і звичаєвості.

На наших очах традиційна весільна обрядовість українського села зазнає скорочення, збіднення та модифікації під впливом міста й масової культури. Усе частіше весілля відбуваються не в домашніх умовах, а в кафе, ресторанах та інших закладах масового харчування. На зміну архаїчним формам святкової гри та розвагам приходять нові стереотипи організації весільних урочистостей, які пропонують і активно впроваджують у життя спеціальні шлюбні агенції та фірми. Замість того, щоб «молотити жито», гостям сьогодні пропонують різноманітні конкурси, вікторини, шоу-програми та екзотичні івенти. Все це фіксується сучасними методами фоно-фото-кіно- й відеозапису, щоб потім стати пам'ятною реліквію сім'ї.

Реальні наслідки взаємодії старих і нових моделей проведення весільного свята повинні стати предметом подальших студій українських етнологів і культурологів.

\section{СПИСОК БІБЛІОГРАФІЧНИХ ПОСИЛАНЬ}

Боплан, Г. Л. (1970). Весільні звичаї українців у першій половині XVII століття. В М. М. Шубравська \& О. А. Правдюк (Упоряд.), Весілля (Кн. 1, с. 63-68). Наукова думка.

Борисенко, В. (Упоряд.) (2012). Традиційне весілля українців: Унікальні записи кінця ХІХ 20-40-х років XX століття. Стилос.

Васютинский, Ф. (1883). Поучение l-е на Новый год против уличных свадебных увеселений. Черниговские епархиальные известия. Неофициальная часть, 7, 359-362.

Вовк, Хв. К. (1995). Студії з української етнографії та антропології. Мистецтво.

Гейзінга, Й. (1994). Ното Ludens. Досвід визначення ігрового елемента культури (О. Мокровольський, пер.). Основи.

Гнедич, И. А. (1915). Материалы по народной словесности Полтавской губернии. Роменский уезд (Вып. 1). Издательство Полтавской Ученой Археографической Комиссии.

Гринченко, Б. Д. (1899). Этнографические материалы, собранные в Черниговской и соседних с ней губерниях (Т. 3). Типография Губернского Земства.

Грінченко, Б. (1958). Словарь української мови (Т. 1). Видавництво АН УРСР.

Грушевський, М. (1993). Історія української літератури (Т. 1). Либідь.

Доленга-Ходаківський, 3. (1974). Українські народні пісні в записах Зоріана Доленги-Ходаківського (з Галичини, Волині, Поділля, Придніпрянщини і Полісся). Наукова думка. 
Кримський, А. (2009). Звенигородщина. Шевченкова батьківщина з погляду етнографічного та діалектологічного. Вертикаль.

Курочкін, О. В. (2004). Українці в сім’ї європейській: звичаї, обряди, свята. Бібліотека українця.

Курочкін, О. В. (2015). Традиційне весілля у контексті розважально-сміхової культури українців. Університет, 2-6, 78-92.

Курочкін, О. В. (2016а). Малодосліджені аспекти традиційного весілля українців. Актуальні питання суспільних наук та історії медицини, 3, 64-68.

Курочкін, О. В. (2016b). Народний обряд «старече весілля». Народна творчість та етнологія, 2, 66-77.

Курочкін, О. В. (2019). Обрядові танці-ігри - малодосліджені компоненти традиційного весілля українців. Танцювальні студї, 2(2), 118-136.

Литвинова-Бартош, П. (1900). Весільні обряди і звичаї у селі Землянці Глухівського повіту у Чернігівщині. В Хв. Вовк (Ред.), Матеріяли до українсько-руської етнології (Т. 3, с. 71-173). 3 друкарні НТШ.

Медведик, П. (Упоряд.). (1996). Село Жабиня на Зборівщині: Весілля. Народні звичаї та обряди. Лілея.

Морозов, И. А. (1999). Игры народные. В Н. И. Толстой (Ред.), Славянские древности: Этнолингвистический словарь (Т. 2, с. 380-386). Международные отношения.

Нечуй-Левицький, І. С. (1965). Микола Джеря. В І. С. Нечуй-Левицький, Зібрання творів у десяти томах (Т. 3, с. 34-142). Наукова думка.

Нечуй-Левицький, I. С. (1966). Українські гумористи та штукарі. В I. С. Нечуй-Левицький, Зібрання творів у десяти томах (Т. 5, с. 356-446). Наукова думка.

Павловський, I. (1926). Весільний обряд Ніженщини (Фонд 1-4, Одиниця зберігання 245). Відділ архівних наукових фондів рукописів та фонозаписів Інституту мистецтвознавства, фольклористики та етнології ім. М. Рильського НАН України, Київ.

Панеш, Э. Х., \& Ермолов, Л. Б. (2000). К вопросу классификации игр. В Народные игры и игрушки (с. 10-27). МАЭ РАН (Кунсткамера).

Старков, В. (2009). Традиційна ігрова культура населення України. Інститут української археографії та джерелознавства ім. М. С. Грушевського.

Успенский, Б. (1996). Мифологический аспект русской экспрессивной фразеологии. В Н. А. Богомолов (Ред.), Анти-мир русской культуры: Язык. Фольклор. Литература (с. 9-107). Ладомир.

Чубинский, П. (1877). Труды этнографическо-статистической экспедиции в Западно-Русский край, снаряженной Императорским Русским географическим обществом (Т. 4). Типография Киршбаума.

Чубинський, П. (1970). Весілля в селі Бориспіль Переяславського повіту Полтавської губернії. В М. М. Шубравська \& О. А. Правдюк (Упоряд.), Весілля (Кн. 1, с. 81-146). Наукова думка.

Щербань, О., \& Яреха, Г. (2008). Весільний обряд села Велика Павлівка (Полтавщина, Україна). Берегиня, 3, 31-68.

Kolberg, O. (1962). Dziela Wszystkie (T. 29: Pokucie, Cz. 1). Ludowa Spółdzielnia Wydawnicza.

\section{REFERENCES}

Beauplan, G. L. (1970). Vesilni zvychai ukraintsiv u pershii polovyni XVII stolittia [Wedding customs of Ukrainians in the first half of the XVII century]. In M. M. Shubravska \& O. A. Pravdiuk (Comps.), Vesillia [Wedding] (Book 1, pp. 63-68). Naukova Dumka [in Ukrainian]. 
Borysenko, V. (Comp.). (2012). Tradytsiine vesillia ukraintsiv: unikalni zapysy kintsia XX - 2040-kh rokiv XX stolittia [Traditional Wedding of Ukrainians: Unique Records of the End of the $X I X-20-40$ s of the XX Century]. Stylos [in Ukrainian].

Chubynskyi, P. (1877). Trudy etnografichesko-statisticheskoi ekspeditsii v Zapadno-Russkii krai, snaryazhennoi Imperatorskim Russkim geograficheskim obshchestvom [Proceedings of an Ethnographic and Statistical Expedition to the West Russian Territory, Equipped by the Imperial Russian Geographical Society] (Vol. 4). Tipografiya Kirshbauma [in Russian].

Chubynskyi, P. (1970). Vesillia v seli Boryspil Pereiaslavskoho povitu Poltavskoi hubernii [Wedding in the Village of Boryspil, Pereyaslav District, Poltava Province]. In M. M. Shubravska \& O. A. Pravdiuk (Comps.), Vesillia [Wedding] (Book 1, pp. 81-146). Naukova Dumka [in Ukrainian].

Dolenha-Khodakivskyi, Z. (1974). Ukrainski narodni pisni v zapysakh Zoriana DolenhyKhodakivskoho (z Halychyny, Volyni, Podillia, Prydniprianshchyny i Polissia) [Ukrainian Folk Songs Recorded by Zorian Dolenga-Khodakivsky (from Galicia, Volyn, Podillya, Prydniprianshchyna and Polissya)]. Naukova Dumka [in Ukrainian].

Gnedich, I. A. (1915). Materialy po narodnoi slovesnosti Poltavskoi gubernii. Romenskii uezd [Materials on Folk Literature of the Poltava Province. Romny District] (Iss. 1). Izdatel'stvo Poltavskoi Uchenoi Apkheograficheskoi Komissii [in Russian].

Hrinchenko, B. (1899). Etnograficheskie materialy, sobrannye $v$ Chernigovskoi i sosednikh s nei guberniyakh [Ethnographic Materials Collected in the Chernigov and Neighboring Provinces] (Vol. 3). Tipografiya Gubernskogo Zemstva [in Russian].

Hrinchenko, B. (1958). Slovar ukrainskoi movy [Dictionary of the Ukrainian Language] (Vol. 1). Vydavnytstvo AN URSR [in Ukrainian].

Hrushevskyi, M. (1993). Istoriia ukrainskoi literatury [History of Ukrainian Literature] (Vol. 1). Lybid [in Ukrainian].

Huizinga, J. (1994). Homo Ludens. Dosvid vyznachennia ihrovoho elementa kultury [Homo Ludens. Experience in Determining the Game Element of Culture] (O. Mokrovolskyi, Trans.). Osnovy [in Ukrainian].

Kolberg, O. (1962). Dziela Wszystkie (T. 29: Pokucie, Cz. 1) [Full Composition of Writings (Vol. 29: Pokuttia, Pt. 1)] Ludowa Spółdzielnia Wydawnicza [in Polish].

Krymskyi, A. (2009). Zvenyhorodshchyna. Shevchenkova batkivshchyna z pohliadu etnohrafichnoho ta dialektolohichnoho [Zvenigorod Region. Shevchenko's Homeland from the Ethnographic and Dialectological Point of View]. Vertykal [in Ukrainian].

Kurochkin, O. V. (2004). Ukraintsi v sim'i yevropeiskii: zvychai, obriady, sviata [Ukrainians in the European Family: Customs, Rituals, Holidays]. Biblioteka Ukraintsia [in Ukrainian].

Kurochkin, O.V. (2015). Tradytsiine vesillia u konteksti rozvazhalno-smikhovoi kultury ukraintsiv [Traditional Wedding in the Context of Entertainment and Humor Culture of Ukrainians]. Universytet, 2-6, 78-92 [in Ukrainian].

Kurochkin, O. V. (2016a). Malodoslidzheni aspekty tradytsiinoho vesillia ukraintsiv [LittleStudied Aspects of the Traditional Wedding of Ukrainians]. Current Issues of Social Sciences and History of Medicine, 3, 64-68 [in Ukrainian].

Kurochkin, O. V. (2016b). Narodnyi obriad "stareche vesillia” [Folk rite “Older Wedding”]. Folk Art and Ethnology, 2, 66-77 [in Ukrainian].

Kurochkin, O. V. (2019). Obriadovi tantsi-ihry - malodoslidzheni komponenty tradytsiinoho vesillia ukraintsiv [Eitual Dance-Games - Little Explored Components of Ukrainian Traditional Wedding]. Dance Studies, 2(2), 118-136 [in Ukrainian].

Lytvynova-Bartosh, P. (1900). Vesilni obriady i zvychai u seli Zemliantsi Hlukhivskoho povitu $\mathrm{u}$ Chernihivshchyni [Wedding Ceremonies and Customs in the Village of Zemlyantsi, Hlukhiv District, Chernihiv Region]. In Khv. Vovk (Ed.), Materiialy do ukrainsko-ruskoi etnolohii [Materials on Ukrainian-Russian Ethnology] (Vol. 3, pp. 71-173). Z Drukarni NTSh [in Ukrainian]. 
Medvedyk, P. (Comp.). (1996). Selo Zhabynia na Zborivshchyni: Vesillia. Narodni zvychai ta obriady [The Village of Zhabynia in the Zboriv Region: Wedding. Folk Customs and Rites]. Lileia [in Ukrainian].

Morozov, I. A. (1999). Igry narodnye [Folk Games]. In N. I. Tolstoi (Ed.), Slavyanskie drevnosti: Etnolingvisticheskii slovar' [Slavic Antiquities: Ethnolinguistic Dictionary] (Vol. 2, pp. 380386). Mezhdunarodnye Otnosheniya [in Russian].

Nechui-Levytskyi, I. S. (1965). Mykola Dzheria [Mykola Dzherya]. In I. S. Nechui-Levytskyi, Zibrannia tvoriv u desiaty tomakh [Collection of Works in Ten Volumes] (Vol. 3, pp. 34-142). Naukova Dumka [in Ukrainian].

Nechui-Levytskyi, I. S. (1966). Ukrainski humorysty ta shtukari [Ukrainian Humorists and Magicians]. In I. S. Nechui-Levytskyi, Zibrannia tvoriv u desiaty tomakh [Collection of Works in Ten Volumes] (Vol. 5, pp. 356-446). Naukova Dumka [in Ukrainian].

Panesh, E. Kh., \& Ermolov, L. B. (2000). K voprosu klassifikatsii igr [On the Classification of Games]. In Narodnye igry i igrushki [Folk Games and Toys] (pp. 10-27). MAE RAN (Kunstkamera) [in Russian].

Pavlovskyi, I. (1926). Vesilnyi obriad Nizhenshchyny [Wedding Ceremony of Nizhenshchyna] (Fund 1-4, Storage Unit 245). Department of Archives Scientific Collections of Manuscripts and Phonorecordings of Institute of Art Studies, Folklore and Ethnology MT Rylsky, Kyiv [in Ukrainian].

Shcherban, O., \& Yarekha, H. (2008). Vesilnyi obriad sela Velyka Pavlivka (Poltavshchyna, Ukraina) [Wedding Ceremony of the Village of Velyka Pavlivka (Poltava region, Ukraine)]. Berehynia, 3, 31-68 [in Ukrainian].

Starkov, V. (2009). Tradytsiina ihrova kultura naselennia Ukrainy [Traditional game culture of the population of Ukraine]. M. S. Hrushevsky Institute of Ukrainian Archaeography and Source Studies [in Ukrainian].

Uspenskii, B. (1996). Mifologicheskii aspekt russkoi ekspressivnoi frazeologii [Mythological Aspect of Russian Expressive Phraseology]. In N. A. Bogomolov (Ed.), Anti-mir russkoi kul'tury: Yazyk. Fol'klor. Literatura [Anti-World of Russian Culture: Language. Folklore. Literature] (pp. 9-107). Ladomir [in Russian].

Vasyutinskii, F. (1883). Pouchenie l-e na Novyi god protiv ulichnykh svadebnykh uveselenii [First Lesson for the New Year Versus Street Wedding Entertainment]. Chernigovskie Eparkhial'nye Izvestiya. Neofitsial'naya Chast', 7, 359-362 [in Russian].

Vovk, Khv. K. (1995). Studii z ukrainskoi etnohrafii ta antropolohii [Studies in Ukrainian Ethnography and Anthropology]. Mystetstvo [in Ukrainian]. 